The Hijacked War 
This page intentionally left blank 


\section{THE HIJACKED WAR}

THE STORY OF CHINESE POWS

IN THE KOREAN WAR

David Cheng Chang

STANFORD UNIVERSITY PRESS

Stanford, California 
STANFORD UNIVERSITY PRESS

Stanford, California

() 2020 by the Board of Trustees of the Leland Stanford Junior University. All rights reserved.

No part of this book may be reproduced or transmitted in any form or by any means, electronic or mechanical, including photocopying and recording, or in any information storage or retrieval system without the prior written permission of Stanford University Press.

This book has been partially underwritten by the Stanford Authors Fund. We are grateful to the Fund for its support of scholarship by first-time authors. For more information, please see www.sup.org/authorsfund.

Printed in the United States of America on acid-free, archival-quality paper

Library of Congress Cataloging-in-Publication Data

Names: Chang, David Cheng, I974- author.

Title: The hijacked war : the story of Chinese POWs in the Korean War /

David Cheng Chang.

Description: Stanford, California : Stanford University Press, 2019. |

Includes bibliographical references and index.

Identifiers: LCCN 2018021585 (print) | LCCN 2018022756 (ebook) | ISBN 978 I 503605879 | ISBN 978 I 503604605 | ISBN 978 I 503604605

(cloth : alk. paper)

Subjects: LCSH: Korean War, I950-1953-Prisoners and prisons, Chinese. |

Korean War, 1950-1953-Personal narratives, Chinese. | Repatriation-

China-History—2oth century. | Repatriation-Taiwan-History-

2oth century. | Communists - China-History—2oth century. | NationalistsChina-History—2oth century. | United States—Foreign relations-

1945-I953. | China-History-Civil War, I945-1949.

Classification: LCC DS921.2 (ebook) | LCC DS921.2 .C43 2019 (print) |

DDC $951.904 / 27-\mathrm{dc} 23$

LC record available at https://lccn.loc.gov/201802 I 585

Typeset by Kevin Barrett Kane in I0/13.5 Adobe Garamond

Cover design: Angela Moody

Cover photograph: G. Dimitria Boria, MacArthur Memorial Archives 
To the more than twenty-one thousand Chinese prisoners of war who returned to China, went to Taiwan, or chose neutral nations

and

to the several hundred Chinese prisoners who perished in UN prison camps or north of the 38 th parallel. 
This page intentionally left blank 